\title{
Article \\ Genetic Gains from Selection for Drought Tolerance during Three Breeding Periods in Extra-Early Maturing Maize Hybrids under Drought and Rainfed Environments
}

\author{
Baffour Badu-Apraku ${ }^{1, *} \mathbb{C}$, Oluwafemi Obisesan ${ }^{1}\left(\mathbb{D}\right.$, Adeoti Abiodun $^{1}$ and Ebenezer Obeng-Bio ${ }^{2} \mathbb{C}$ \\ 1 International Institute of Tropical Agriculture (IITA), PMB 5320, Ibadan 200001, Nigeria; \\ femiobisesan@gmail.com (O.O.); iita.dtmamaize@gmail.com (A.A.) \\ 2 Crops Research Institute, Kumasi 3785, Ghana; obengbio2000@gmail.com \\ * Correspondence: b.badu-apraku@cgiar.org; Tel.: +234-810-848-2590
}

Citation: Badu-Apraku, B.; Obisesan, O.; Abiodun, A.; Obeng-Bio, E. Genetic Gains from Selection for Drought Tolerance during Three Breeding Periods in Extra-Early Maturing Maize Hybrids under Drought and Rainfed Environments. Agronomy 2021, 11, 831

https://doi.org/10.3390/

agronomy11050831

Received: 21 March 2021

Accepted: 20 April 2021

Published: 23 April 2021

Publisher's Note: MDPI stays neutral with regard to jurisdictional claims in published maps and institutional affiliations.

Copyright: () 2021 by the authors. Licensee MDPI, Basel, Switzerland. This article is an open access article distributed under the terms and conditions of the Creative Commons Attribution (CC BY) license (https:// creativecommons.org/licenses/by/ $4.0 /)$.

\begin{abstract}
Genetic gain studies in a breeding program are very important for measuring the efficiency of the program over a specific period. It also provides breeders with an understanding of the outcomes of the huge investments committed to the breeding programs. This study sought to (i) estimate the gains in grain yield under drought and rainfed conditions and (ii) identify highyielding and stable hybrids developed in the last two decades under drought and rainfed conditions. Sixty extra-early maturing hybrids developed by the International Institute of Tropical Agriculture (IITA), Ibadan, during three breeding periods: (2008-2010, 2011-2013, and 2014-2016) were assessed under managed drought and rainfed conditions across 14 environments in Nigeria to estimate the genetic gains in grain yield using linear regression analysis. Considerably high genetic gains $(4.1 \%)$ per year for grain yield was obtained for the extra-early maturing hybrids under drought environments. Six of the top ten hybrids identified were from period 3, an indication of the high genetic gains from selection in period 3. Additionally, two of the top six period 3 hybrids (TZEEI $29 \times$ TZEEI 13) $\times$ TZEEI 64 and TZdEEI $64 \times$ TZEEI 54 were found to be the best yielding and most stable across the 14 test environments and were highly recommended for extensive evaluations to warrant their commercialization in sub-Saharan Africa (SSA).
\end{abstract}

Keywords: genetic gain; drought and rainfed management; Zea mays L.

\section{Introduction}

Maize is extremely relevant in the production systems of sub-Saharan Africa (SSA) with over $85 \%$ of the rural people dependent on it as a staple food crop [1,2] and also because of its increasing demand for industrial uses including animal feed, agro-allied, and brewery industries. Additionally, the ability of maize to fit into the various cropping systems in SSA and its high response to good management conditions in relation to other cereals makes it the most suitable crop for combating food shortages in the subregion [3]. In the savannas of SSA, cultivation and use of the extra-early (80-85 days to obtain physiological maturity) maturing varieties [4] have been phenomenal in bridging the hunger gap within the cropping cycle, especially in the rural communities. This has paved the way for the acceptance of the extra-early maize varieties in areas of shorter unimodal rainfall distribution of the savanna of SSA which until a few decades ago had not been considered suitable for intensive maize cultivation [3]. The adaptation of maize to this zone is attributed to the relatively low disease and pest incidences, cool night temperatures, and high solar radiation incidence, all of which make the savanna the most important agro-ecological zone for maize production [3]. Nonetheless, the production of maize in SSA is faced by a myriad of constraints including Striga hermonthica infestation, drought, and low soil fertility. The combined effects of these stresses often result in total loss of the maize crop $[5,6]$. The effects of climate change, because of global warming, has further increased 
the probability of these stresses to occur especially, drought [7]. Drought stress alone could lead to $40-90 \%$ loss in grain yield (GY) if it occurs at the same time as the flowering (anthesis and silking) or grain-filling periods [8-10]. Grain yield losses of 53\% was reported when early maturing maize varieties were tested under drought environments in Nigeria [11]. Bänziger et al. [12] also reported yield losses during grain-filling, tasseling, flowering and the number of days before tassel emergence to be $21 \%, 22 \%, 50 \%$, and $90 \%$ respectively.

The development and availability of extra-early maturing maize cultivars characterized by shorter growing cycle have provided farmers with maize cultivars that possess the potential to reduce the hunger gap as a result of the recurrent drought that occurs from November to March in the savanna agro-ecological zones of SSA [3]. This is because such maize cultivars mature more quickly in the season relative to other indigenous cereal crops including millet and sorghum $[3,13]$. The short maturity period of the extra-early maize is another unique advantage it has over other crops in the various agro-ecological zones of SSA because farmers can plant it in an intercropping system for it to mature quickly while the other crops take over for the rest of the growing season [14]. In many communities of SSA, the extra-early maize plays a critical role as a food security crop since it is harvested and consumed fresh (green maize) very early in the growing season to end hunger resulting from depletion of food reserves of the previous season. The extra-early maize is also mostly preferred to other staple crops because it responds better to fertilizer application and other management practices which contribute to high productivity [13].

The early and extra-early breeding program of the IITA Maize Improvement Program (IITA-MIP) has the ultimate goal of developing varieties with a high degree of tolerance to multiple stresses resulting from either biotic or abiotic factors. The program has placed a major emphasis on the development of germplasm with enhanced resistance or tolerance to biotic stresses such as Striga, maize streak virus (MSV), rust, turcicum, leaf blight, and abiotic stresses, including drought, heat, combined drought and heat, and low soil $\mathrm{N}$ for all agro-ecologies of SSA. The focus of the IITA-MIP is on developing multiple stress-resistant/tolerant genetic source populations (using recurrent selection) for further breeding [3]. As a result, several open-pollinated varieties (OPVs), inbreds, and different types of hybrids with enhanced low N, Striga resistance and drought tolerance have been developed. The two stresses have been found to be critical abiotic constraints to efficient production of maize in SSA [15-17]. NeSmith and Ritchie [18] suggested that about $90 \%$ grain yield loss due to drought occurs just before and after tassel emergence. The increased drought stress severity in SSA is attributed to changes in global climatic conditions, reduction in soil organic matter of cultivated fields, preference of high-value crops on available fields as well as poor water holding capacity of soils [12]. Flower abortion resulting from female sterility and delayed silking imposes a great negative impact on maize [19], and severely reduce yield [20]. Globally, drought is estimated to cause about 24 million tons worth of yield loss annually, which is approximately about $17 \%$ of the expected production in the developing world in a normal year [21].

The IITA-MIP has been consistently providing stress-resistant/tolerant extra-early and early cultivars to maize growers in WCA since maize production moved from the forest to the savanna agro-ecological zone about three decades ago. However, it had long been recognized that to accelerate the onward march of the extra-early maize from the forest agro-ecology to the savannas of WCA, it was of crucial importance to emphasize the development of cultivars adaptable to the savanna agro-ecological zone. Since 2001, the IITA-MIP has developed several extra-early populations with superior Striga resistance and drought and low $\mathrm{N}$ tolerance from which inbred lines, and cultivars have been derived under WCA tropical conditions to mitigate the threat of recurrent drought, Striga infestation, and low N in the savanna areas of the sub-region. In 2011, some extra-early droughttolerant inbred lines were identified by IITA-MIP, facilitating the development and use of drought-tolerant extra-early hybrids [3].

For more than two decades, much attention has been paid to the development of extra-early maize hybrids at IITA. Three breeding periods have been established in the IITA 
hybrid maize program based on the germplasm, methodologies and strategies adopted. It was believed that assessment of the genetic improvement in terms of grain yield and related agronomic traits from one breeding period to the other during the past two decades could be beneficial in identifying important traits to accelerate genetic gains in the hybrid development program $[22,23]$. However, the direct relationship between grain yield potential and related traits of the drought-tolerant extra-early hybrids developed during the three breeding periods [24] had not been assessed to understand the rationale behind the huge investments in the breeding program [25]. It is therefore of vital importance to determine the extent of progress made in breeding for extra-early hybrids tolerant to drought in the specified breeding periods.

Genetic gain studies have contributed to a better understanding of the breeding progress of maize cultivars developed in different eras [22-24,26-29]. Results of genetic gain studies have revealed significant increases in grain yield between generations of cultivars. For example, Badu-Apraku et al. [28] reported annual genetic gains of $1.2 \%$ and average grain yield of $30 \mathrm{~kg} \mathrm{ha}^{-1} \mathrm{yr}^{-1}$ under multiple stress conditions in breeding open-pollinated extra-early maturing maize cultivars during three breeding eras from 1988 to 2000, (period 1), 2001 to 2006 (period 2), and 2007 to 2010 (period 3). Furthermore, Badu-Apraku et al. [24] reported a $2.56 \%$ annual gains from selection of extra-early OPVs with a mean increase in rate of gain of $42 \mathrm{~kg} \mathrm{ha}^{-1} \mathrm{yr}^{-1}$ under Striga-infested conditions. Similarly, Badu-Apraku et al. [29] indicated annual grain yield gains of $44 \mathrm{~kg} \mathrm{ha}^{-1} \mathrm{yr}^{-1}$ and $2.72 \%$ for 56 extra-early OPVs under different stress environments (drought, low-N, and Striga-infestation). However, no study has reported on the breeding progress of the extraearly hybrids generated in the last two decades. The objectives of the present study are to (i) estimate grain yield gains in sixty extra-early hybrids with subsets developed in three breeding periods (2008-2010, 2011-2013, and 2014-2016) and (ii) identify high-yielding and stable candidates among the 60 hybrids under drought and rainfed conditions.

\section{Materials and Methods}

\subsection{Background of the Drought-Tolerant Extra-Early Hybrids}

The 60 extra-early maturing hybrids (involving single-crosses, 3-way crosses, top crosses and double-crosses) were generated during three breeding periods in the IITA-MIP from 2008 to 2010 (period 1), 2011 to 2013 (period 2), and 2014 to 2016 (period 3) respectively (Table 1). In each period, an in-depth description of the strategies adopted for developing the hybrids has been reported $[3,30]$.

Table 1. Extra-early maturing maize hybrids used for the genetic gain study and the period of development.

\begin{tabular}{cccc}
\hline Entry & Variety & Year & Period \\
\hline 1 & TZEEI $82 \times$ TZEEI 79 & 2008 & 1 \\
\hline 2 & TZEEI 95 $\times$ TZEEI 58 & 2008 & 1 \\
\hline 3 & TZEEI 79 $\times$ TZEEI 76 & 2008 & 1 \\
\hline 4 & $($ TZEEI 95 $\times$ TZEEI 79 $) \times$ TZEEI 63 & 2010 & 1 \\
\hline 5 & $($ TZEEI 79 $\times$ TZEEI 58) $\times$ TZEEI 95 & 2010 & 1 \\
\hline 6 & $($ TZEEI 95 $\times$ TZEEI 58) $\times($ TZEEI 82 $\times$ TZEEI 79) & 2010 & 1 \\
\hline 7 & $($ TZEEI 95 $\times$ TZEEI 63) $\times($ TZEEI 79 $\times$ TZEEI 58) & 2010 & 1 \\
\hline 8 & TZEE-Y Pop STR C5 $\times$ TZEEI 67 & 2010 & 1 \\
\hline 9 & TZEE-Y Pop STR C5 $\times$ TZEEI 95 & 2008 & 1 \\
\hline 10 & TZEE-Y Pop STR C5 $\times$ TZEEI 58 & 2008 & 1 \\
\hline
\end{tabular}


Table 1. Cont.

\begin{tabular}{|c|c|c|c|}
\hline Entry & Variety & Year & Period \\
\hline 11 & TZEE-Y Pop STR C5 × TZEEI 82 & 2010 & 1 \\
\hline 12 & TZEEI $29 \times$ TZEEI 49 & 2010 & 1 \\
\hline 13 & TZEEI $29 \times$ TZEEI 21 & 2010 & 1 \\
\hline 14 & $($ TZEEI $29 \times$ TZEEI 21) $\times$ TZEEI 55 & 2010 & 1 \\
\hline 15 & $($ TZEEI $4 \times$ TZEEI 49) $\times$ TZEEI 29 & 2010 & 1 \\
\hline 16 & $($ TZEEI $29 \times$ TZEEI 21$) \times$ TZEEI 14 & 2010 & 1 \\
\hline 17 & $($ TZEEI $29 \times$ TZEEI 21$) \times($ TZEEI $4 \times$ TZEEI 14$)$ & 2010 & 1 \\
\hline 18 & TZEE -W Pop STR C5 × TZEEI 21 & 2010 & 1 \\
\hline 19 & TZEEI $79 \times$ TZEEI 58 & 2008 & 1 \\
\hline 20 & TZEE-W Pop STR C5 × TZEEI 6 & 2010 & 1 \\
\hline 21 & TZEEI $100 \times$ TZEEI 63 & 2011 & 2 \\
\hline 22 & TZEEI $64 \times$ TZEEI 79 & 2011 & 2 \\
\hline 23 & TZEEI $87 \times$ TZEEI 76 & 2012 & 2 \\
\hline 24 & TZEEI $81 \times$ TZEEI 96 & 2012 & 2 \\
\hline 25 & TZEEI $71 \times$ TZEEI 79 & 2011 & 2 \\
\hline 26 & TZEEI $9 \times$ TZEEI 79 & 2011 & 2 \\
\hline 27 & TZEEI $112 \times$ TZEEI 29 & 2011 & 2 \\
\hline 28 & TZEEI $110 \times$ TZEEI 29 & 2011 & 2 \\
\hline 29 & TZEEI $15 \times$ TZEEI 29 & 2011 & 2 \\
\hline 30 & TZEEI $48 \times$ TZEEI 29 & 2011 & 2 \\
\hline 31 & TZEEI $12 \times$ TZEEI 21 & 2011 & 2 \\
\hline 32 & TZEEI $14 \times$ TZEEI 29 & 2011 & 2 \\
\hline 33 & $($ TZEEI $29 \times$ TZEEI 13) $\times$ TZEEI 10 & 2013 & 2 \\
\hline 34 & TZEEI $36 \times$ TZEEI 14 & 2013 & 2 \\
\hline 35 & TZEEI $95 \times$ TZEEI $79 \times$ TZEEI 81 & 2013 & 2 \\
\hline 36 & TZEEI $96 \times$ TZEEI $73 \times$ TZEEI 67 & 2013 & 2 \\
\hline 37 & $($ TZEEI $29 \times$ TZEEI 13) $\times$ TZEEI 34 & 2013 & 2 \\
\hline 38 & TZEEI $29 \times$ TZEEI $14 \times$ TZEEI 10 & 2013 & 2 \\
\hline 39 & TZEEI $15 \times$ TZEEI $21 \times$ TZEEI 14 & 2013 & 2 \\
\hline 40 & TZEEI $29 \times$ TZEEI $14 \times$ TZEEI 37 & 2013 & 2 \\
\hline 41 & TZdEEI $1 \times$ TZdEEI 12 & 2013 & 2 \\
\hline 42 & TZdEEI $4 \times$ TZEEI 58 & 2015 & 3 \\
\hline 43 & TZdEEI $2 \times$ TZEEI 63 & 2015 & 3 \\
\hline 44 & TZdEEI $7 \times$ TZEEI 79 & 2015 & 3 \\
\hline 45 & TZdEEI $7 \times$ TZEEI 58 & 2015 & 3 \\
\hline 46 & TZdEEI $11 \times$ TZdEEI 12 & 2013 & 2 \\
\hline 47 & TZdEEI $12 \times$ TZdEEI 58 & 2013 & 2 \\
\hline 48 & TZdEEI $11 \times$ TZdEEI 79 & 2013 & 2 \\
\hline 49 & TZdEEI $50 \times$ TZEEI 29 & 2015 & 3 \\
\hline 50 & TZdEEI $64 \times$ TZEEI 54 & 2015 & 3 \\
\hline
\end{tabular}


Table 1. Cont.

\begin{tabular}{cccc}
\hline Entry & Variety & Year & Period \\
\hline 51 & TZdEEI $54 \times$ TZEEI 29 & 2015 & 3 \\
\hline 52 & TZdEEI 34 $\times$ TZEEI 29 & 2015 & 3 \\
\hline 53 & $($ TZEEI $29 \times$ TZEEI 13) $\times$ TZdEEI 50 & 2015 & 3 \\
\hline 54 & $($ TZEEI $29 \times$ TZEEI 14 $) \times$ TZdEEI 64 & 2015 & 3 \\
\hline 55 & TZEEI 29 $\times$ TZEEI 13 $\times$ TZdEEI 90 & 2015 & 3 \\
\hline 56 & TZEEI 29 $\times$ TZEEI 13 $\times$ TZdEEI 51 & 2015 & 3 \\
\hline 57 & TZEEI 29 $\times$ TZEEI 13 $\times$ TZdEEI 64 & 2015 & 3 \\
\hline 58 & TZEEI 29 $\times$ TZEEI 14 $\times$ TZdEEI 90 & 2015 & 3 \\
\hline 59 & 2009 TZEE-OR1 STR $\times$ TZdEEI 12 & 2016 & 3 \\
\hline 60 & 2009 TZEE-OR1 STR $\times$ TZdEEI 7 & 2016 & 3 \\
\hline
\end{tabular}

Briefly, a breeding program was initiated in 1994 by the IITA/WECAMAN (West and Central Africa Collaborative Maize Research Network) [31] to improve extra-early maize for Striga resistance and drought tolerance. The program extensively tested several landraces and exotic germplasm in West and Central Africa (WCA) with the aim of coming up with extra-early drought-escaping maize cultivars. By 1996, five breeding populations had been developed by IITA-WECAMAN through multi-environment evaluations and selection from crosses between local and exotic germplasm [32,33]. Outstanding genotypes were identified based on per se grain yield, earliness, MSV resistance, and tolerance to drought and heat which characterized the Sudan Savanna in WCA. Source populations including TZEE-W Pop STR $C_{0}$ and TZEE-Y Pop STR $C_{0}$ with backgrounds of maize streak virus (MSV) and Striga resistance, and drought tolerance, as well as crosses involving TZEE-Y SR $\mathrm{BC}_{1} \times 9450$ STR, TZEE-W Pop STR $\times$ LD, and TZEE-W SR BC $5 \times 1368$ STR were used for the development of extra-early inbred lines. From a source population, superior $S_{1}$ lines were selected to carry out an inbreeding program up to $S_{6}$ coupled with selection under Striga-infested environments. About 250-300 inbreds (at cycle 4) extracted from a population were crossed as the tester to the same base population. Using this strategy, the IITA-MIP developed several extra-early maize inbreds and hybrids with combined tolerance to drought and low N, and Striga resistance from the source populations using well planned breeding procedures including introgression, inbreeding, and hybridization [3].

Before 1994, maize cultivars available in SSA could hardly tolerate S. hermonthica and drought stresses. The IITA-WECAMAN Maize Program had by 1998 developed extra-early OPVs, inbreds, and hybrids with Striga tolerance levels ranging from moderate to high The Striga tolerant inbred lines, 9030 STR, 9450 STR, and 1368 STR were used to develop the Striga-resistant varieties [33-35]. Striga resistant genes were introgressed into each of the two populations, TZEE-W Pop STR $C_{0}$ and TZEE-Y Pop STR $C_{0}$ followed by five cycles of $S_{1}$ recurrent selection for improvement of the Striga resistance levels. This resulted in the development of the two Striga resistant populations, TZEE-Y Pop STR $C_{5}$ and TZEE -W Pop STR $C_{5}$. At that time, the proposition was to improve the extra-early germplasm for tolerance to multiple stresses. Results of several evaluations in our program revealed clear indications of the presence of drought and low soil nitrogen (low N) tolerance genes in the extra-early maize germplasm in WCA. This led to the identification of a large number of extra-early inbreds and hybrids that did not only escape drought but also had both low $\mathrm{N}$ and drought tolerance genes [10]. Furthermore, the selected outstanding lines were subjected to evaluations under Striga infestation in Nigeria. The Striga-resistant, and drought and low $\mathrm{N}$ tolerant inbreds identified were assessed in hybrid combinations under the multiple stresses and under rainfed environments in Nigeria. These inbreds served as parents for the hybrids used in the present study. Drought-tolerant hybrids identified 
in the program were categorized into three periods of development (60 hybrids for each period) for the present genetic gain study.

\subsection{Field Evaluations}

In the first set of experiments, the 60 extra-early hybrids were assessed under induced drought environments in 2016/2017, 2018/2019, and 2019/2020 dry seasons at Ikenne, Nigeria $\left(6^{\circ} 54^{\prime} \mathrm{N}, 3^{\circ} 42^{\prime} \mathrm{E}, 1200 \mathrm{~mm}\right.$ rainfall amount per year, $60 \mathrm{~m}$ altitude). The trials were established in the dry seasons and $17 \mathrm{~mm}$ of water was applied to the plots at weekly intervals using a sprinkler irrigation system. Drought was achieved by irrigating the plots for the first 25 days after planting after which irrigation was terminated for the plants to be supported by the residual soil moisture until harvesting. The trials were established following a $10 \times 6$ (10 entries in 6 blocks) randomized incomplete block design using 3 replicates. Two row plots, each measuring $4 \mathrm{~m}$ with $0.75 \times 0.4 \mathrm{~m}$ spacing were used. Seeds were planted to ensure the establishment of 2 seedlings per hill which resulted in 66,666 plants ha ${ }^{-1}$. Sixty $\mathrm{kg}$ each of $\mathrm{N}, \mathrm{P}_{2} \mathrm{O}_{5}$ and $\mathrm{K}_{2} \mathrm{O} \mathrm{ha}^{-1}$ was applied as basal fertilizer during planting while $30 \mathrm{~kg}$ of $\mathrm{N} \mathrm{ha}^{-1}$ was applied as top-dressing just before irrigation was withdrawn. In the second set of experiments, the hybrids were planted under rainfed conditions during the 2017, 2019, and 2020 growing seasons at the same location (Ikenne) following the experimental design as described for the drought trials. However, the basal fertilizer was applied at 2 weeks after planting (WAP) and top-dressed at 4 WAP. Under both management conditions, weeds were controlled using herbicides and manual means as and when necessary.

\subsection{Data Collection}

Data on days to $50 \%$ silking (DS) and anthesis (DA) were taken and the difference between the two flowering days was the anthesis-silking interval (ASI). The distances from the soil level of the plant to the level of the upper ear node, and to the first tassel branch were measured as the ear height (EHT) and plant height (PHT), respectively. Additionally, data on the number of plants that leaned beyond $30^{\circ}$ away from the vertical and those broken at or just below the node of the upper ear were taken (and expressed as percentage) as root and stalk lodging, respectively, while ears per plant (EPP) was obtained on plot basis by dividing the number of ears harvested (EHARV) by the corresponding plants harvested (PHARV). Plant aspect (PASP) was rated using a 1 to 9 scale by taking into account the overall phenotypic appeal of the plants per plot, where $1=$ excellent overall appeal of the plants and $9=$ poor overall appeal of the plants. Ear aspect (EASP) was assessed on a 1 to 9 scale, with 1 denoting large, well-filled, clean, and uniform ears and 9 representing ears with undesirable characteristics. On a 1 to 9 scale, husk cover (HUSK) was scored where 1 = ears with long and firmed husks that fully covered the tip and $9=$ ears with exposed tips. Additionally, under managed drought, stay green characteristic (STGR) was recorded at 10 WAP on a 1 to 9 scale, where 1 indicated plants with over $80 \%$ of the leaf area dead, and 9 denoted plants with less than $10 \%$ of the leaf area dead. Grain weight (GWT) was determined from completely shelled ears per plot and percentage grain moisture content (GMC) was measured. Grain yield (GY, $\mathrm{kg} \mathrm{ha}^{-1}$ ) adjusted to a moisture content of $15 \%$ was derived from cob weight (field weight) and moisture content of grains per plot as follows:

$$
\mathrm{GY}=\mathrm{GWT} \frac{100-\mathrm{GMC}}{85} \times \frac{10,000}{8 \times \Phi}
$$

where, GY = grain yield $\left(\mathrm{kg} \mathrm{ha}^{-1}\right), \mathrm{GWT}=$ weight of grain per plot $(\mathrm{kg}), \mathrm{GMC}=$ moisture content of grain at harvest, $10,000 \mathrm{~m}^{2}=$ land area ha ${ }^{-1}, 8=$ land area per hill $(0.75 \mathrm{~m} \times 0.4 \mathrm{~m}), \Phi=$ number of hills/plot (11). However, $80 \%$ shelling percentage was used for the hybrids for the computation of GY under rainfed conditions. 


\subsection{Statistical Analysis}

Data obtained for GY and related measured traits were used for the combined analysis of variance (ANOVA) with PROC GLM in SAS 9.4 [36] to obtain mean squares for each trait. The combined ANOVA had genotypes as a fixed factor, while environments, period, replicates, environment $\times$ period, and the remaining sources of variation were regarded as random factors. The environment was regarded as the combination of location and year. Similarly, separate ANOVA was performed for the two moisture regimes and means of traits were estimated for the hybrids. Means of the 60 hybrids (developed in the three breeding periods) for each trait were regressed on the periods (year of development of the hybrids) to calculate gains per year. Moreover, means of GY and related traits of the 60 hybrids (dependent variable) were regressed on the year in which the hybrid was generated (independent variable) to compute the linear regression coefficient (b value). The genetic gain per annum was estimated by dividing the $b$ value as the numerator by the intercept as the denominator and multiplied by hundred [35] as follows;

$$
{\operatorname{gg~} \mathrm{yr}^{-1}}^{-1} \frac{\mathrm{b} \text { value }}{\text { Intercept }} \times 100
$$

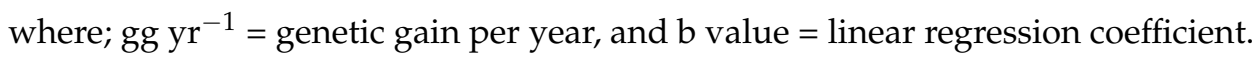

Similarly, mean GY of hybrids was regressed on the breeding periods to obtain the yield gain per period. A similar procedure was followed to estimate the yearly yield gains for hybrids of each of the periods. Broad-sense heritability values $\left(\mathrm{H}^{2}\right)$ for GY were calculated for the drought, rainfed, and across management conditions as follows:

$$
\mathrm{H}^{2}=\frac{\sigma_{\mathrm{g}}^{2}}{\sigma_{\mathrm{g}}^{2}+\frac{\sigma_{\mathrm{gE}}^{2}}{\mathrm{e}}+\frac{\sigma^{2}}{\mathrm{re}}}
$$

where $\sigma_{\mathrm{g}}^{2}$ is the variance of genotype, $\sigma_{\mathrm{gE}}^{2}$ is genotype $\times$ environment variance, $\sigma^{2}$ is variance of error, $\mathrm{e}$ is the number of environments and $\mathrm{r}$ is the replications within environments [37].

The best performing hybrids under moisture-limited environments were identified with the aid of the multiple trait base index (MI) involving high GY with good agronomic characters [9]. Using the MI, 35 hybrids (top 20 drought tolerant, mid five, and 10 most drought susceptible) were used in a GGE biplot analysis which investigated the main effects of genotypes and also its interaction with the environment [38] to identify hybrids that yielded high with better stability across the environments where they were tested.

\section{Results}

The ANOVA for the combined data of the 60 extra-early hybrids revealed a significant variance for GY and the related traits for period, environment (Env), hybrid, Env $\times$ Hybrid, and Env $\times$ period (Table 2). The sum of squares for GY from the ANOVA for period, environment (Env), Hybrid and Hybrid $\times$ Env were 2.7, 69.1, 5.6, and 14\% of the overall sum of squares across drought and well-watered conditions. This indicated that each research condition was distinct from the others; hence, performing separate ANOVA for the two different soil moisture conditions was necessary. ANOVA for the hybrids under moisture stress showed a highly significant variance for GY and other traits for Env, Hybrid (period), period, and Env $\times$ Hybrid (period) except period for ASI, stalk lodging, ear rot and STGR and Env $\times$ Hybrid for PHT, EHT, ear rot and STGR. Env $\times$ period was significant for all traits measured excluding DA, EHT, plant, and ear aspects. Under rainfed conditions, there were significant mean squares for GY and other traits for Env, period, Hybrid (period), Env $\times$ Hybrid (period), and Env $\times$ period except for Env $\times$ period for PHT, EHT, and ear rot. The repeatability values estimated for measured traits under drought conditions ranged from 0.39 for 
ear rot to 0.73 for DA. Under well-watered conditions, repeatability values varied from 0.21 for ASI to 0.78 for ear aspect. Under drought conditions, measured traits had repeatability estimates greater than 0.5 except for ASI and ear rot. High repeatability estimates were observed for grain yield under both soil moisture regimes (0.72 under drought conditions and 0.76 under rainfed conditions). Similarly, STGR (0.65) and EPP (0.67) had high repeatability estimates when moisture was limiting. Grain yield and other traits under well-watered conditions recorded repeatability estimates higher than 0.5 except for percent stalk lodging and ASI. Grain yield under drought conditions varied from $1389 \mathrm{~kg} \mathrm{ha}^{-1}$ for period 1 hybrids to $1659 \mathrm{~kg} \mathrm{ha}^{-1}$ for period 3 hybrids with a relative genetic gain of $4.1 \%$ per year and an average rate of increase in GY of $46.5 \mathrm{~kg} \mathrm{ha}^{-1}$ year $^{-1}$ (Tables 3 and 4). Under rainfed conditions, GY varied from $3678 \mathrm{~kg} \mathrm{ha}^{-1}$ for period 1 hybrids to $4577 \mathrm{~kg} \mathrm{ha}^{-1}$ for period 3 hybrids, with a relative genetic gain of $4.15 \%$ per year and an average rate of increase of $140.2 \mathrm{~kg} \mathrm{ha}^{-1} \mathrm{year}^{-1}$. Anthesis-silking interval was significantly associated with genetic gains in GY between periods 1 to 3 under drought conditions although there were no significant differences among the periods for ASI. Regression of GY of hybrids under optimal growing conditions on the GY under drought conditions revealed differences in the performance of hybrids developed in each of the three periods (Figure 1). Higher grain yield was recorded among the period 3 hybrids under both soil moisture regimes, except in some few cases where some period 3 hybrids recorded grain yield similar to those of some period 1 and 2 hybrids. Six out of the top ten hybrids under drought were period 3 hybrids while two were from period 2 and the other two from period 1. Similarly, six out of the ten best hybrids were from period 3, four from period 2, and two were from period 1 hybrids when grain yield under drought conditions was regressed on GY across moisture stress and non-stress conditions (Figure 2). Period 3 hybrids displayed superior performance under drought, well-watered, and across growing conditions.

Table 2. Mean squares for grain yield and other agronomic traits of extra-early maize hybrids evaluated under drought, well-watered, and across research conditions in Nigeria between 2016 and 2019.

\begin{tabular}{|c|c|c|c|c|c|c|c|c|c|c|c|}
\hline Source $^{+}$ & Df & $\begin{array}{c}\text { Grain Yield, (kg } \\
\text { ha }^{-1} \text { ) }\end{array}$ & $\begin{array}{l}\text { Anthesis Silking } \\
\text { Interval }\end{array}$ & $\begin{array}{l}\text { Plant Height } \\
(\mathrm{cm})\end{array}$ & $\begin{array}{l}\text { Ear Height } \\
(\mathrm{cm})\end{array}$ & $\begin{array}{c}\text { Stalk } \\
\text { Lodging (\%) }\end{array}$ & Ear Aspect & Ear Rot & Ears/Plant & $\begin{array}{c}\text { Plant } \\
\text { Aspect }\end{array}$ & $\begin{array}{l}\text { Stay Green } \\
\text { Xtics }\end{array}$ \\
\hline \multicolumn{12}{|c|}{ Drought condition } \\
\hline Block (Rep × ENV) & 45 & $1254881^{* *}$ & $11.30^{* *}$ & $458.03 * *$ & 189.71 ** & 20.05 ** & $2.09 * *$ & $14.17^{* *}$ & $0.052 * *$ & 1.51 ** & 1.08 ** \\
\hline Rep (ENV) & 6 & $190546 \mathrm{~ns}$ & 6.2 & $394.47 * *$ & $169.84^{*}$ & $59.78 * *$ & 4.25 ** & $80.29 * *$ & $0.051 * *$ & 1.72 ** & 1.99 ** \\
\hline Era & 2 & $2885469 * *$ & 10.16 & $1389.61 * *$ & 532.03 ** & $9.21 \mathrm{~ns}$ & $9.93 * *$ & $9.52 \mathrm{~ns}$ & 0.203 ** & $5.04 * *$ & 0.85 \\
\hline ENV & 2 & 48563216 ** & 1022.67 ** & 31023.69 ** & $1446.79 * *$ & $544.29 * *$ & 18.58 ** & $188.93 * *$ & $3.674 * *$ & $69.12 * *$ & 77.74 ** \\
\hline Hybrid (Era) & 57 & 1185780 ** & $8.77 * *$ & 508.01 ** & $219.27 * *$ & $59.32 * *$ & $1.63 * *$ & 10.22 ** & 0.068 ** & $1.25 * *$ & $2.54^{* *}$ \\
\hline ENV $\times$ Hybrid (Era) & 114 & $367057 *$ & 4.90 ** & 154.43 & 81.06 & $16.44 * *$ & $0.74 * *$ & 6.16 & $0.025 * *$ & 0.58 ** & 0.86 \\
\hline $\mathrm{ENV} \times \mathrm{Era}$ & 4 & 471453 & 0.9 & 280.12 & $199.88^{*}$ & 18.85 & $0.82^{*}$ & 2.4 & 0.006 & $1.33 *$ & 0.91 \\
\hline Error & 309 & 272813 & 3.42 & 134.61 & 74.28 & 11.06 & 0.58 & 6.52 & 0.017 & 0.4 & 0.42 \\
\hline \multirow{2}{*}{\multicolumn{12}{|c|}{ Well-watered condition }} \\
\hline & & & & & & & & & & & \\
\hline Block (Rep $\times$ ENV) & 90 & 1680222 * & $0.31 \mathrm{~ns}$ & $513.37 * *$ & $284.42 * *$ & $22.87 * *$ & 1.00 ** & $9.77^{* *}$ & $0.02 * *$ & 1.08 ** & - \\
\hline Rep (ENV) & 12 & $2971597 * *$ & 0.70 ** & 1074.50 ** & $685.59 * *$ & $58.22 * *$ & 2.59 ** & $59.65 * *$ & $0.01 \mathrm{~ns}$ & $2.91 * *$ & - \\
\hline Era & 2 & 60071418 ** & $3.03^{* *}$ & $3713.70^{*}$ & $1860.17^{* *}$ & 451.35 ** & $53.62 * *$ & $17.17^{* *}$ & $0.26^{* *}$ & $19.00 * *$ & - \\
\hline ENV & 5 & 53702086 ** & $94.88 * *$ & $38577.22 * *$ & $22681.00 * *$ & $12986.70 * *$ & $181.89 * *$ & 1551.35 ** & 0.75 ** & $29.75 * *$ & - \\
\hline Hybrid (Era) & 57 & $3666304 * *$ & $0.87^{* *}$ & $733.24 * *$ & $397.74 * *$ & $181.37^{* *}$ & 2.31 ** & $13.59 * *$ & 0.03 ** & $1.79 * *$ & - \\
\hline ENV $\times$ Hybrid (Era) & 285 & 1312636 ** & 0.70 ** & 210.38 ** & 122.51 ** & 102.65 ** & 0.80 ** & $4.79 * *$ & $0.01 \mathrm{~ns}$ & 0.77 ** & - \\
\hline ENV*Era & 10 & 2814491 ** & 2.14 ** & $201.22 \mathrm{~ns}$ & $102.11 \mathrm{~ns}$ & 329.50 ** & $3.12 * *$ & $3.66 \mathrm{~ns}$ & $0.02^{*}$ & $1.13^{* *}$ & - \\
\hline ERROR & 618 & 492828 & 0.31 & 157.18 & 76.04 & 22.53 & 0.43 & 3.15 & 0.01 & 0.39 & - \\
\hline Heritability & & 0.76 & 0.21 & 0.76 & 0.74 & 0.43 & 0.78 & 0.66 & 0.66 & 0.67 & - \\
\hline \multicolumn{12}{|c|}{ Across research environments } \\
\hline Block (Rep $\times$ ENV) & 135 & 1538442 ** & $3.98 * *$ & $494.92 * *$ & 252.85 ** & $21.93 \mathrm{~ns}$ & 1.36 ** & $11.24 * *$ & $0.028 * *$ & $1.22 * *$ & - \\
\hline Rep (ENV) & 18 & $2044580 * *$ & $2.54^{*}$ & 847.82 ** & $513.68 * *$ & $58.74 * *$ & $3.14 * *$ & 66.53 ** & 0.026 ** & 2.51 ** & - \\
\hline Era & 2 & 53159421 ** & $10.28 * *$ & $4973.71^{* *}$ & 2327.94 ** & 244.48 ** & 60.78 ** & $9.47 \mathrm{~ns}$ & $0.439 * *$ & $23.54 * *$ & $=$ \\
\hline Environment (ENV) & 8 & $341757186 * *$ & 518.42 ** & 63559.17 ** & 17511.44 ** & $8534.31^{* *}$ & $153.80^{* *}$ & $1016.84^{* *}$ & $6.012 * *$ & 43.56 ** & - \\
\hline Cultivar (Era) & 57 & $3635019 * *$ & $4.68^{* *}$ & $902.30 * *$ & $513.40^{* *}$ & $199.66 * *$ & $2.41^{* *}$ & $17.86 * *$ & $0.058 * *$ & $2.23 * *$ & - \\
\hline ENV $\times$ Cultivar (Era) & 456 & $1064295^{* *}$ & 2.28 ** & $212.46 * *$ & $109.79 * *$ & $73.39 * *$ & 0.88 ** & $5.28 * *$ & 0.020 ** & 0.73 ** & - \\
\hline ENV $\times$ Era & 16 & 3101603 ** & $1.92 \mathrm{~ns}$ & $211.99 \mathrm{~ns}$ & $121.82 \mathrm{~ns}$ & $237.66 * *$ & 2.50 ** & $5.04 \mathrm{~ns}$ & $0.018 \mathrm{~ns}$ & $1.10^{* *}$ & - \\
\hline Error & 927 & 419489 & 1.34 & 149.66 & 75.45 & 18.71 & 0.48 & 4.27 & 0.01 & 0.40 & - \\
\hline Heritability & & 0.79 & 0.54 & 0.80 & 0.81 & 0.61 & 0.79 & 0.70 & 0.73 & 0.75 & \\
\hline
\end{tabular}

,$+ * * *$ Significant $\mathrm{F}$ test at 0.05 and 0.01 levels of probability, respectively; Rep = replication; Env = environment. 
Table 3. Mean grain yield and other agronomic traits of extra-early maize hybrids of three breeding periods assessed under drought at Ikenne during 2016-2019 dry seasons.

\begin{tabular}{|c|c|c|c|c|}
\hline \multirow[t]{2}{*}{ Trait } & \multirow[t]{2}{*}{ Era } & \multirow{2}{*}{$\begin{array}{l}\text { Number } \\
\text { of Hybrids }\end{array}$} & \multicolumn{2}{|c|}{ Research Condition } \\
\hline & & & Drought & Well-Watered \\
\hline \multirow[t]{3}{*}{ Grain yield, kg ha ${ }^{-1}$} & $2008-2010$ & 20 & $1389 \pm 101.0$ & $3678 \pm 108.7$ \\
\hline & 2011-2013 & 24 & $1474 \pm 60.4$ & $4078 \pm 109.7$ \\
\hline & 2014-2016 & 16 & $1659 \pm 96.6$ & $4577 \pm 78.7$ \\
\hline \multirow[t]{3}{*}{ Days to anthesis } & 2008-2010 & 20 & $48 \pm 0.17$ & $50 \pm 0.27$ \\
\hline & 2011-2013 & 24 & $49 \pm 0.27$ & $52 \pm 0.34$ \\
\hline & 2014-2016 & 16 & $49 \pm 0.20$ & $51 \pm 0.23$ \\
\hline \multirow[t]{3}{*}{ Days to silking } & $2008-2010$ & 20 & $51 \pm 0.32$ & $51 \pm 0.26$ \\
\hline & 2011-2013 & 24 & $52 \pm 0.35$ & $52 \pm 0.31$ \\
\hline & $2014-2016$ & 16 & $51 \pm 0.29$ & $52 \pm 0.21$ \\
\hline \multirow[t]{3}{*}{ Anthesis silking interval } & 2008-2010 & 20 & $3 \pm 0.26$ & $1 \pm 0.06$ \\
\hline & 2011-2013 & 24 & $3 \pm 0.20$ & $1 \pm 0.04$ \\
\hline & 2014-2016 & 16 & $3 \pm 0.24$ & $1 \pm 0.04$ \\
\hline \multirow[t]{3}{*}{ Plant height, cm } & 2008-2010 & 20 & $157 \pm 1.72$ & $182 \pm 1.56$ \\
\hline & 2011-2013 & 24 & $157 \pm 1.36$ & $184 \pm 1.40$ \\
\hline & 2014-2016 & 16 & $162 \pm 1.96$ & $189 \pm 1.51$ \\
\hline \multirow[t]{3}{*}{ Ear height, cm } & $2008-2010$ & 20 & $77 \pm 1.30$ & $85 \pm 1.24$ \\
\hline & 2011-2013 & 24 & $79 \pm 0.93$ & $88 \pm 0.99$ \\
\hline & 2014-2016 & 16 & $81 \pm 1.08$ & $89 \pm 0.96$ \\
\hline \multirow[t]{3}{*}{ Root lodging (\%) } & 2008-2010 & 20 & $0.4 \pm 0.10$ & $2.8 \pm 0.39$ \\
\hline & 2011-2013 & 24 & $0.5 \pm 0.16$ & $2.3 \pm 0.31$ \\
\hline & 2014-2016 & 16 & $0.6 \pm 0.16$ & $2.2 \pm 0.39$ \\
\hline \multirow[t]{3}{*}{ Stalk lodging (\%) } & 2008-2010 & 20 & $2.6 \pm 0.42$ & $6.8 \pm 0.64$ \\
\hline & 2011-2013 & 24 & $3.1 \pm 0.52$ & $4.6 \pm 0.78$ \\
\hline & 2014-2016 & 16 & $3.0 \pm 0.87$ & $4.9 \pm 0.77$ \\
\hline \multirow[t]{3}{*}{ Husk cover } & $2008-2010$ & 20 & $3.7 \pm 0.10$ & $3.8 \pm 0.09$ \\
\hline & 2011-2013 & 24 & $3.5 \pm 0.06$ & $3.5 \pm 0.07$ \\
\hline & 2014-2016 & 16 & $3.6 \pm 0.11$ & $3.2 \pm 0.06$ \\
\hline \multirow[t]{3}{*}{ Plant aspect } & 2008-2010 & 20 & $5.3 \pm 0.10$ & $5.0 \pm 0.09$ \\
\hline & 2011-2013 & 24 & $5.1 \pm 0.06$ & $4.7 \pm 0.06$ \\
\hline & 2014-2016 & 16 & $5.0 \pm 0.10$ & $4.5 \pm 0.06$ \\
\hline \multirow[t]{3}{*}{ Ear aspect } & 2008-2010 & 20 & $5.2 \pm 0.12$ & $4.5 \pm 0.09$ \\
\hline & 2011-2013 & 24 & $4.9 \pm 0.07$ & $4.0 \pm 0.08$ \\
\hline & 2014-2016 & 16 & $4.7 \pm 0.10$ & $3.6 \pm 0.07$ \\
\hline \multirow[t]{3}{*}{ Ear rot } & 2008-2010 & 20 & $2.6 \pm 0.19$ & $2.8 \pm 0.17$ \\
\hline & 2011-2013 & 24 & $2.4 \pm 0.23$ & $2.7 \pm 0.21$ \\
\hline & 2014-2016 & 16 & $2.9 \pm 0.36$ & $2.4 \pm 0.20$ \\
\hline \multirow[t]{3}{*}{ Stay green characteristic } & 2008-2010 & 20 & $3.9 \pm 0.12$ & - \\
\hline & 2011-2013 & 24 & $3.8 \pm 0.12$ & - \\
\hline & $2014-2016$ & 16 & $3.9 \pm 0.12$ & - \\
\hline \multirow[t]{3}{*}{ Ears per plant } & 2008-2010 & 20 & $0.5 \pm 0.023$ & $0.9 \pm 0.010$ \\
\hline & $2011-2013$ & 24 & $0.6 \pm 0.014$ & $0.9 \pm 0.008$ \\
\hline & 2014-2016 & 16 & $0.6 \pm 0.023$ & $0.9 \pm 0.010$ \\
\hline
\end{tabular}


Table 4. Relative genetic gains of grain yield and other traits of extra-early hybrids of three breeding periods assessed under drought environments between 2016 and 2019 and rainfed environments between 2016 and 2017 in Nigeria.

\begin{tabular}{|c|c|c|c|c|c|c|c|c|}
\hline \multirow[b]{2}{*}{ Trait } & \multicolumn{2}{|c|}{$\begin{array}{l}\text { Relative Gain } \\
\text { (\% Per Year) }\end{array}$} & \multicolumn{2}{|c|}{$\mathbf{R}^{2}$} & \multicolumn{2}{|c|}{ a } & \multicolumn{2}{|c|}{$\mathbf{b}$} \\
\hline & DS & WW & DS & WW & DS & WW & DS & WW \\
\hline Grain yield, $\left(\mathrm{kg} \mathrm{ha}^{-1}\right)$ & 4.14 & 4.15 & 0.159 & 0.33 & 1446.8 & 3376.2 & $46.536^{*}$ & $140.25^{* *}$ \\
\hline Days to anthesis & 0.07 & 0.31 & 0.003 & 0.064 & 50.96 & 50.34 & $0.086 \mathrm{~ns}$ & $0.157 *$ \\
\hline Days to silk & 0.05 & 0.25 & 0.001 & 0.057 & 53.56 & 51.23 & $0.003 \mathrm{~ns}$ & $0.127 \mathrm{~ns}$ \\
\hline $\begin{array}{l}\text { Anthesis silking } \\
\text { interval }\end{array}$ & -0.41 & -3.2 & 0.002 & 0.097 & 2.6 & 0.96 & $-0.083 \mathrm{~ns}$ & $-0.031^{*}$ \\
\hline Plant height (cm) & 1.14 & 0.51 & 0.08 & 0.092 & 135.09 & 180.43 & 1.016 * & $0.913 * *$ \\
\hline Ear height (cm) & 1.33 & 0.08 & 0.1 & 0.091 & 68.69 & 84.15 & $0.624 *$ & $0.066^{* *}$ \\
\hline Root lodging (\%) & -0.4 & -3.72 & 0 & 0.029 & 0.58 & 3.06 & $0.034 \mathrm{~ns}$ & $-0.114 *$ \\
\hline Stalk lodging (\%) & -5.45 & -3.6 & 0.059 & 0.027 & 2.25 & 6.61 & $0.072 \mathrm{~ns}$ & $-0.238 \mathrm{~ns}$ \\
\hline Husk cover & 0.21 & -2.43 & 0.003 & 0.328 & 3.51 & 4.01 & $-0.012 \mathrm{~ns}$ & $-0.097^{* *}$ \\
\hline Plant aspect & -0.97 & -1.5 & 0.128 & 0.233 & 5.6 & 5.09 & $-0.065^{* *}$ & $-0.076^{* *}$ \\
\hline Ear aspect & -1.31 & -2.63 & 0.143 & 0.035 & 5.15 & 4.68 & $-0.081^{* *}$ & $-0.123 * *$ \\
\hline Ear rot & 1.24 & -2.01 & 0.004 & 0.024 & 2.41 & 2.93 & $0.018 \mathrm{~ns}$ & $-0.059 \mathrm{~ns}$ \\
\hline Stay green character & -0.44 & & 0.008 & & 3.85 & & $0.006 \mathrm{~ns}$ & \\
\hline Ears/plant & 1.14 & 1.02 & 0.071 & 0.187 & 0.65 & 0.86 & $0.014^{* *}$ & $0.09 * *$ \\
\hline
\end{tabular}

$* * * *$ Significant at 0.05 and 0.01 probability levels respectively, $\mathrm{ns}=$ not significant, $\mathrm{WW}, \mathrm{DS}=$ well-watered and drought stress respectively, $\mathrm{R}^{2}=$ coefficient of determination, $\mathrm{a}=$ intercept, and $\mathrm{b}=$ linear regression coefficient.

Under drought stress, a significant and positive correlation was found between GY and plant and ear heights, and between GY and EPP (Table 5). However, DS, ASI, stalk lodging, PASP, and EASP had negative and significant correlations with GY. Stay green characteristic had significant negative correlations with plant and ear heights as compared to the significant and positive correlations with, PASP, husk cover, root and stalk lodging, and ear rot. Ear aspect had a significant and positive correlation with DS and ASI but had a significant and negative correlation with plant and ear heights. Under rainfed management conditions, there was a significant and positive association between GY and DA, DS, PHT, EHT, and EPP. In contrast, significant and negative correlations existed between GY and ASI, plant and ear aspects, root and stalk lodging, husk cover, and ear rot. Plant aspect had positive relationship with ASI, root lodging, and husk cover. In contrast, negative and significant correlations existed between PASP, DA, DS, and plant and ear heights. Figure 3A displays the mean of GY versus stability of the selected hybrids under drought conditions at Ikenne and rainfed conditions at six locations in Nigeria during the three breeding periods (2008 and 2016.) The first principal component axis (PC 1) explained $52.8 \%$ while PC 2 accounted for $11.2 \%$, respectively. Thus, the biplot explained $64 \%$ of the total variation in GY. In the genotype main effect plus genotype $\times$ environment (GGE) biplot output, the single arrowed line passing through the origin of the biplot and the average tester is termed the average-tester coordinate abscissa while the double arrowed line (i.e., ATC ordinate) separates the entries into two categories (left and right sides). To the right side of the line are those hybrids with above-average grain yield while to the left side of the line are the hybrids with below-average grain yield. The GY performance of a genotype is measured by the distance from its position onto the ATC ordinate while yield stability is approximated by the projection from its position onto the ATC abscissa (Yan et al., 2007). Figure 3A shows the stability and performance of the hybrids across the 14 research environments. The hybrid with the longest projection on the abscissa is the one that has the highest yield, while the hybrid with a zero projection on the ATC ordinate is the most stable. Based on these criteria, the hybrid with these two attributes is considered as the ideal. This implies that an ideal cultivar should combine high grain yield with better stability as well as other desirable agronomic traits across the experimental sites. 


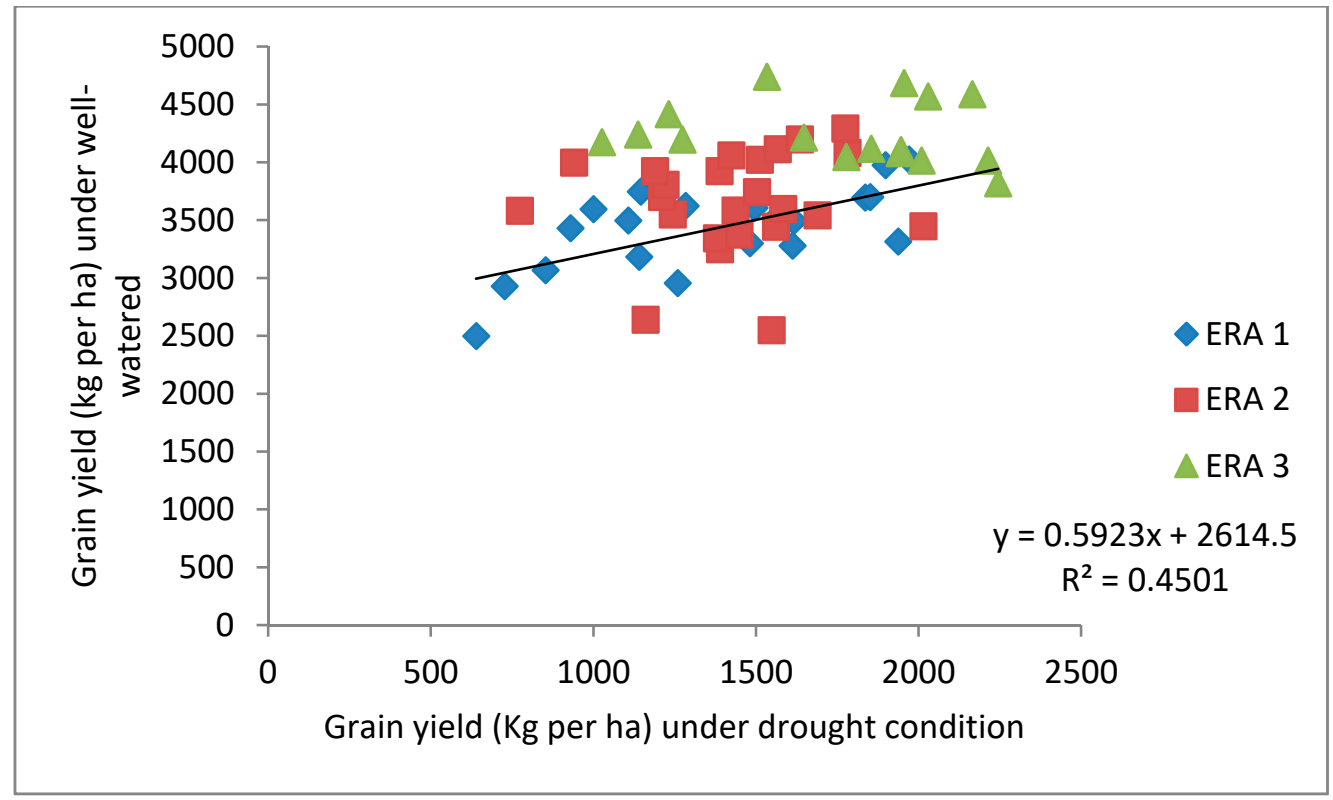

Figure 1. Performance of extra-early maize hybrids of three breeding periods under drought conditions versus rainfed conditions.

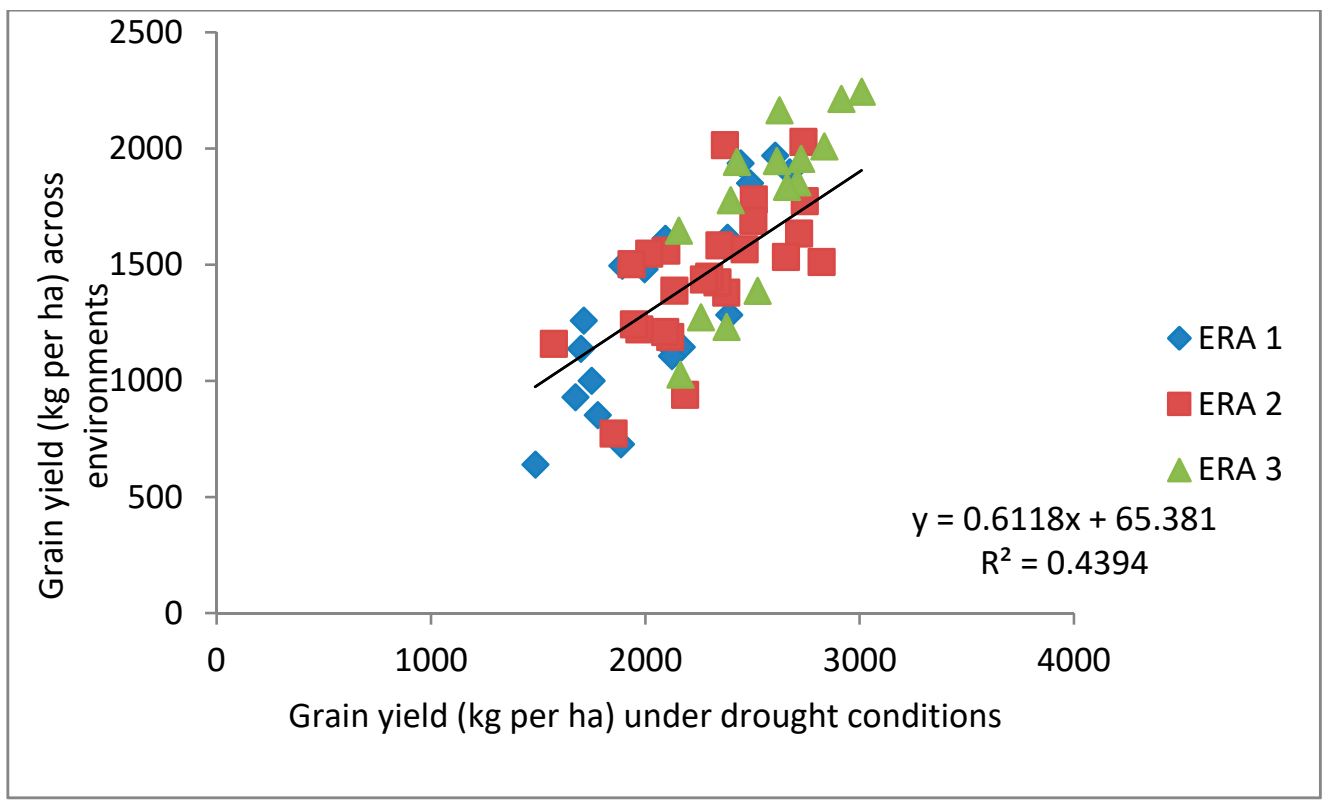

Figure 2. Performance of extra-early maize hybrids of three breeding periods under drought conditions versus across research environments. 
Table 5. Correlation coefficients of grain yield and other agronomic traits of extra-early maize hybrids of three breeding eras evaluated in 3 locations under drought (upper diagonal) and six locations under rainfed (lower diagonal) conditions between 2016 and 2019 in Nigeria.

\begin{tabular}{|c|c|c|c|c|c|c|c|c|c|c|c|c|c|c|}
\hline & $\begin{array}{l}\text { Grain } \\
\text { Yield, } \\
\text { kg/ha }\end{array}$ & $\begin{array}{l}\text { Days to } \\
\text { Anthesis }\end{array}$ & $\begin{array}{l}\text { Days to } \\
\text { Silking }\end{array}$ & ASI & $\begin{array}{c}\text { Plant } \\
\text { Height, } \\
\text { cm }\end{array}$ & $\begin{array}{c}\text { Ear } \\
\text { Height, } \\
\text { cm }\end{array}$ & $\begin{array}{c}\text { Root } \\
\text { Lodging }\end{array}$ & $\begin{array}{c}\text { Stalk } \\
\text { Lodging }\end{array}$ & $\begin{array}{l}\text { Husk } \\
\text { Cover }\end{array}$ & $\begin{array}{c}\text { Plant } \\
\text { Aspect }\end{array}$ & $\begin{array}{c}\text { Ear } \\
\text { Aspect }\end{array}$ & Ear Rot & STGR & Ears/Plant \\
\hline Grain yield, $\mathrm{kg} / \mathrm{ha}$ & & -0.132 & -0.60 ** & $-0.74 * *$ & 0.33 ** & $0.32 *$ & 0.03 & $-0.28 *$ & -0.16 & -0.65 ** & $-0.80^{* *}$ & 0.08 & -0.06 & 0.76 ** \\
\hline Days to anthesis & 0.31 * & & $0.73^{* *}$ & 0.02 & 0.05 & 0.2 & $-0.29 *$ & -0.13 & -0.2 & -0.12 & 0.01 & -0.35 ** & -0.25 & 0.01 \\
\hline Days to silking & $0.26^{*}$ & $0.99 * *$ & & $0.70^{* *}$ & -0.15 & -0.05 & -0.23 & 0.02 & 0.08 & $0.35^{* *}$ & $0.52 * *$ & $-0.33 * *$ & -0.01 & $-0.45 * *$ \\
\hline ASI & $-0.32 *$ & $-0.47 *$ & -0.33 * & & $-0.28 *$ & $-0.28^{*}$ & -0.03 & 0.17 & $0.32 *$ & $0.64 * *$ & $0.75 * *$ & -0.12 & 0.25 & $-0.66^{* *}$ \\
\hline Plant height, $\mathrm{cm}$ & 0.43 ** & 0.46 ** & $0.42 * *$ & $-0.39 * *$ & & 0.78 ** & -0.11 & -0.11 & -0.39 ** & -0.66 ** & -0.43 ** & -0.1 & -0.35 ** & $0.42 * *$ \\
\hline Ear height, $\mathrm{cm}$ & 0.47 ** & 0.58 ** & $0.53 * *$ & -0.49 ** & 0.91 ** & & $\begin{array}{l}-0.11 \\
-0.04\end{array}$ & -0.11 & -0.35 ** & -0.61 ** & -0.41 ** & $\begin{array}{l}-0.1 \\
-0.25\end{array}$ & -0.35 ** & $0.32^{*}$ \\
\hline Root lodging & -0.60 ** & -0.23 & -0.2 & 0.16 & -0.05 & -0.16 & & $0.47^{* *}$ & $0.27 *$ & 0.11 & -0.05 & $0.34 * *$ & $0.27^{*}$ & 0.14 \\
\hline Stalk lodging & $-0.43 * *$ & -0.19 & -0.19 & 0.03 & 0.18 & -0.01 & 0.61 ** & & 0.18 & $0.34 * *$ & 0.18 & $0.27 *$ & $0.37^{* *}$ & $\begin{array}{l}-0.19 \\
-0.19\end{array}$ \\
\hline Husk cover & $-0.72 * *$ & $-0.53 * *$ & -0.48 ** & $0.48 * *$ & -0.55 ** & $-0.63^{* *}$ & 0.51 ** & 0.28 * & & 0.59 ** & 0.40 ** & $0.33 * *$ & $0.41^{* *}$ & $-0.34 * *$ \\
\hline Plant aspect & -0.76 ** & $-0.53 * *$ & $-0.47^{* *}$ & $0.49 * *$ & $-0.66^{* *}$ & $-0.74 * *$ & 0.48 ** & 0.23 & 0.80 ** & & 0.83 ** & 0.19 & $0.42 * *$ & $-0.72 * *$ \\
\hline Ear aspect & -0.91 ** & $-0.34 * *$ & -0.31 * & $0.32 *$ & -0.55 ** & -0.60 ** & 0.47 ** & $0.39 * *$ & 0.71 ** & 0.80 ** & & -0.02 & 0.17633 & -0.83 ** \\
\hline Ear rot & $-0.41 * *$ & -0.38 ** & $-0.38 * *$ & 0.09 & -0.31 * & $-0.40 * *$ & $0.40 * *$ & $0.41 * *$ & 0.54 ** & $0.44 *$ & 0.48 ** & & $0.47^{* *}$ & 0.07 \\
\hline STGR & - & - & - & - & - & - & - & - & . & - & & - & & -0.14 \\
\hline Ears/ plant & $0.33 * *$ & 0.42 ** & 0.36 ** & $-0.45^{* *}$ & 0.45 ** & 0.50 ** & -0.18 & -0.15 & $-0.52 * *$ & $-0.49 * *$ & $-0.34^{* *}$ & $-0.40^{* *}$ & & \\
\hline
\end{tabular}

$*,^{* *}=$ significance at 0.05 and 0.01 probability levels, respectively.

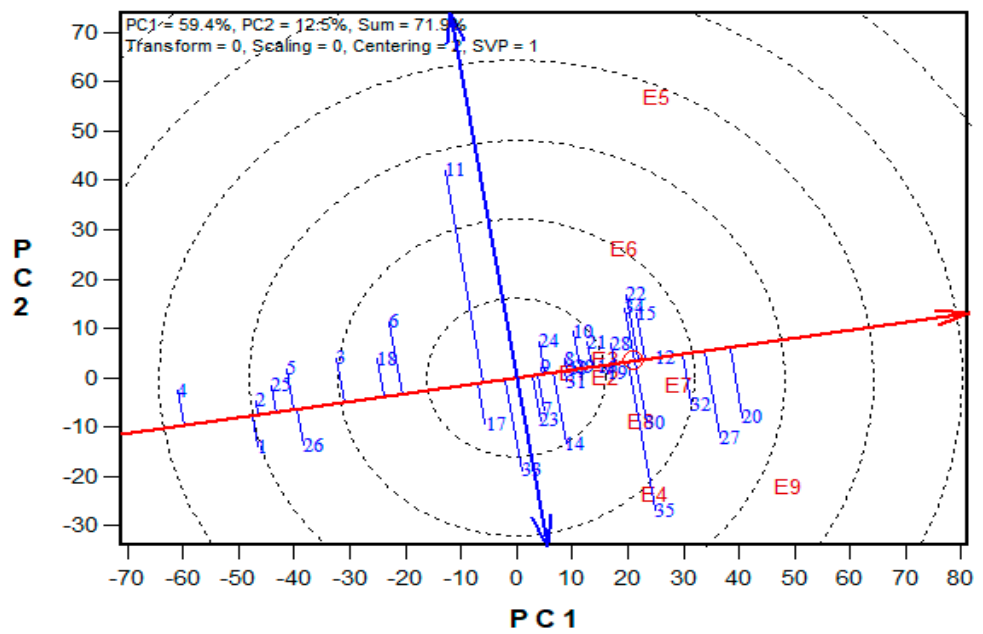

\begin{tabular}{|c|c|}
\hline Entry & Hybrids \\
\hline 1 & TZEEI $82 \times$ TZEEI 79 \\
\hline 2 & TZEEI $95 \times$ TZEEI 58 \\
\hline 3 & $($ TZEEI $79 \times$ TZEEI 58) $\times$ TZEEI 95 \\
\hline 4 & $\begin{array}{c}\text { TZEEI } 95 \times \text { TZEEI 58) } \times(\text { TZEEI } 82 \times \\
\text { TZEEI 79) }\end{array}$ \\
\hline 5 & $\begin{array}{c}(\text { TZEEI } 95 \times \text { TZEEI } 63) \times(\text { TZEEI } 79 \times \\
\text { TZEEI 58) }\end{array}$ \\
\hline 6 & TZEE-Y Pop STR C $5 \times$ TZEEI 82 \\
\hline 7 & TZEEI $29 \times$ TZEEI 49 \\
\hline 8 & TZEEI $29 \times$ TZEEI 21 \\
\hline 9 & $($ TZEEI $29 \times$ TZEEI 21$) \times$ TZEEI 55 \\
\hline 10 & $($ TZEEI $29 \times$ TZEEI 21$) \times$ TZEEI 14 \\
\hline 11 & TZEEI $100 \times$ TZEEI 63 \\
\hline 12 & TZEEI $112 \times$ TZEEI 29 \\
\hline 13 & TZEEI $110 \times$ TZEEI 29 \\
\hline 14 & TZEEI $15 \times$ TZEEI 29 \\
\hline 15 & TZEEI $14 \times$ TZEEI 29 \\
\hline 16 & $($ TZEEI $29 \times$ TZEEI 13) $\times$ TZEEI 10 \\
\hline 17 & TZEEI $95 \times$ TZEEI $79 \times$ TZEEI 81 \\
\hline 18 & TZEEI $96 \times$ TZEEI $73 \times$ TZEEI 67 \\
\hline 19 & (TZEEI $29 \times$ TZEEI 13) $\times$ TZEEI 34 \\
\hline 20 & TZEEI $29 \times$ TZEEI $14 \times$ TZEEI 10 \\
\hline 21 & TZEEI $29 \times$ TZEEI $14 \times$ TZEEI 37 \\
\hline 22 & TZdEEI $2 \times$ TZEEI 63 \\
\hline 23 & TZdEEI $7 \times$ TZEEI 79 \\
\hline 24 & TZdEEI $7 \times$ TZEEI 58 \\
\hline 25 & TZdEEI $12 \times$ TZdEEI 58 \\
\hline 26 & TZdEEI $11 \times$ TZdEEI 79 \\
\hline 27 & TZdEEI $64 \times$ TZEEI 54 \\
\hline 28 & TZdEEI $34 \times$ TZEEI 29 \\
\hline 29 & $($ TZEEI $29 \times$ TZEEI 13) $\times$ TZdEEI 50 \\
\hline 30 & $($ TZEEI $29 \times$ TZEEI 14$) \times$ TZdEEI 64 \\
\hline 31 & TZEEI $29 \times$ TZEEI $13 \times$ TZdEEI 90 \\
\hline 32 & TZEEI $29 \times$ TZEEI $13 \times$ TZdEEI 64 \\
\hline 33 & TZEEI $29 \times$ TZEEI $14 \times$ TZdEEI 90 \\
\hline 34 & 2009 TZEE-OR1 STR $\times$ TZdEEI 12 \\
\hline 35 & 2009 TZEE-OR1 STR $\times$ TZdEEI 7 \\
\hline
\end{tabular}

(A)

Figure 3. Cont. 


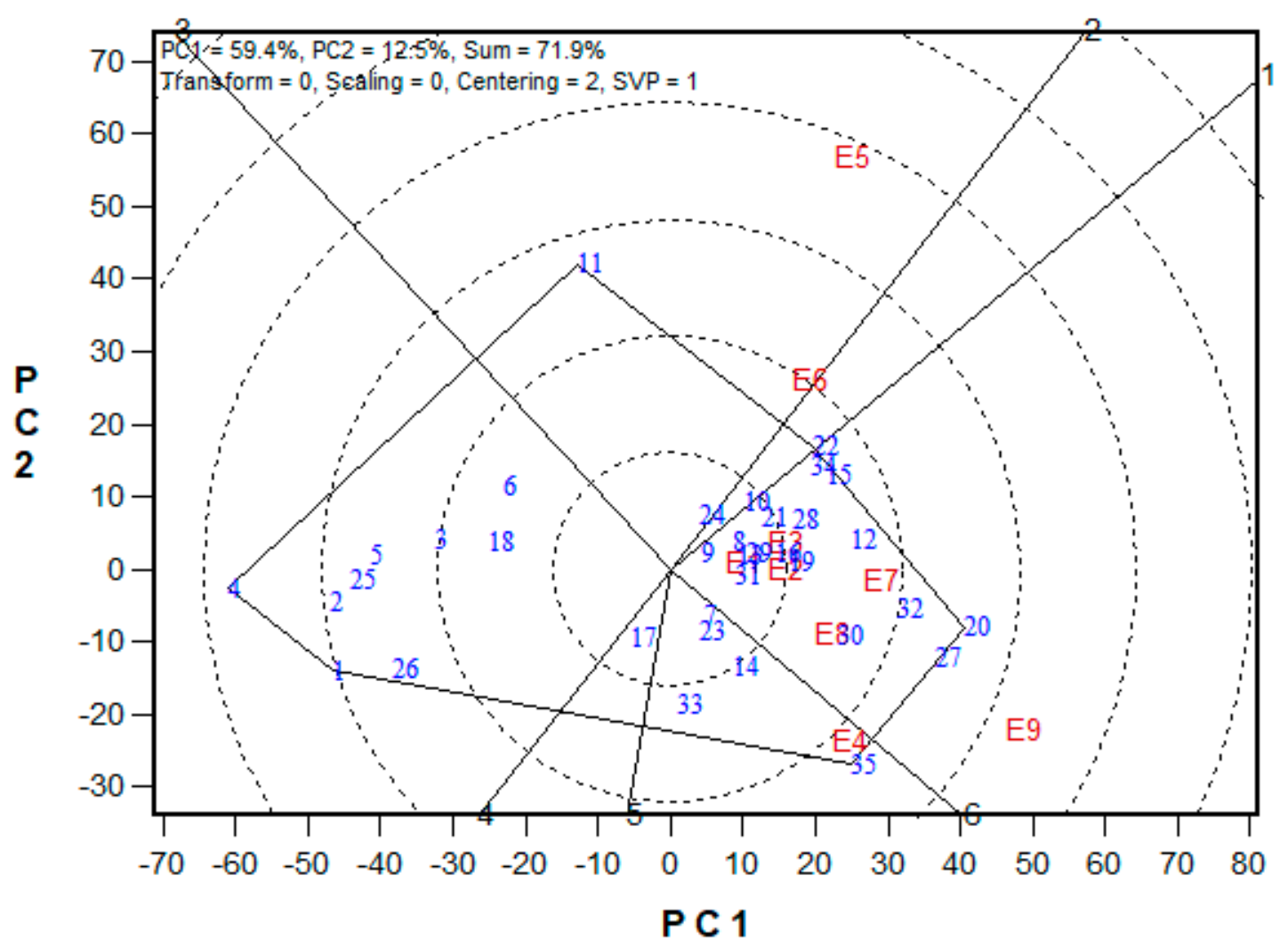

(B)

Figure 3. (A). A biplot display (mean vs. stability) based on genotype $\times$ environment data of 35 extra-early maturing hybrids assessed in 14 environments under drought and rainfed conditions from 2016 to 2019. E1 = Ikenne drought 16. , $\mathrm{E} 2=$ Ikenne drought 18, E3 = Ikenne drought 19, E4 = Ikenne rainfed 16, E5 = Kano rainfed 16, $\mathrm{E} 6=$ Zaria rainfed 16, E7 = Ikenne rainfed 17, E8 = Bagauda rainfed 17, E9 = Zaria rainfed 17. (B). A Which-won where or what based on a genotype $\times$ environment yield data of 35 extra-early maturing hybrids evaluated across 14 environments (including drought and rainfed conditions) from 2016 to 2019.

Hybrids TZdEEI $64 \times$ TZEEI 54, TZEEI $112 \times$ TZEEI 29, (TZEEI $29 \times$ TZEEI 13) $\times$ TZdEEI 64 and (TZEEI $29 \times$ TZEEI 14) $\times$ TZdEEI 10 were the highest yielding across research environments, whereas TZEEI $112 \times$ TZEEI 29 was the most stable among the four hybrids. The which-won-where view of the biplot shows the hybrids that performed best in each location (Figure 3B). Hybrid (TZEEI $29 \times$ TZEEI 14) $\times$ TZEEI 10 performed best under rainfed conditions at Zaria (2017), Ikenne (2017), and Bagauda (2017) and under drought conditions at Ikenne (2018, 2016 and 2019). Hybrid (TZEEI $100 \times$ TZEEI 63) was more adapted to rainfed conditions at Bagauda and Zaria in 2016.

\section{Discussion}

The significant mean squares detected for GY and most measured traits for the 60 extraearly hybrids under both drought and well-watered conditions suggested high genetic variability among the hybrids under both moisture stress and optimal growing conditions. The significant Env $\times$ hybrid (period), and period mean squares indicated that the hybrids performed differently under contrasting moisture conditions within different periods and that the environments and the periods were distinct enough to reveal the differences among the genotypes $[10,25,39]$. These results also suggested large variability in environmental factors particularly soil type (water holding capacity) and rainfall amount [40], as well as temperature ranges during the growing seasons at the experimental site, particularly at Ikenne. These results suggested that more environments are necessary to extensively evaluate a set of hybrids to ensure accelerated genetic gains from selection [41]. The 
observed significant interaction between breeding period, environments, and hybrids also substantiated the variability in the responses of the hybrids to contrasting soil moisture regimes. Therefore, identification of stable and superior yielding hybrids across drought and rainfed conditions would be necessary for this set of hybrids to maximize the yield potential [42,43]. Additionally, classification and evaluation of the hybrids based on the period of development was justified since the period source of variation revealed significant variances for GY and most studied traits [44]. Furthermore, the high repeatability values obtained for GY, and other important measured traits including ears/plant, plant and ear aspects, stay green characteristic and plant and ear heights under drought and rainfed conditions highlighted the potential of the parental inbred lines in transferring desirable characteristics to manifest in superior hybrid performance [13,45]. The staygreen characteristic and number of ears/plants had high repeatability estimates affirming the reliability of the two traits in selecting desirable genotypes especially under drought conditions [9]. Additionally, the very high repeatability values obtained for grain yield under both drought and rainfed environments indicated that direct selection for high grainyielding ability would be effective [46]. Contrarily, the low repeatability estimates recorded for ASI under the two contrasting moisture conditions implied low genetic variability for days DA and DS among the extra-early hybrids. This observation affirmed that the classification of the parental lines involved in the hybrid combinations into the extra-early group (80-85 days to physiological maturity) as the derived hybrids did not vary very much in terms of DA and DS. Similar findings were found by Berner et al. [47] and BaduApraku et al. [23] who ascribed the low repeatability of ASI to the low variation for the number of days to anthesis and silking among the test crosses evaluated.

Grain yield of hybrids (period 1 to 3 ) under drought was regressed on the yields under rainfed conditions. The analysis revealed high grain-yielding ability for the period 3 hybrids compared to those of periods 1 and 2 . This elucidated the magnitude of progress made in the period 3 hybrids as far as high yield was concerned. From the regression analysis, it was easy to identify the superior period 3 hybrids under drought, rainfed, and across environments compared to those of period 1 and 2 . These results, therefore, justified the efforts and resources expended by the IITA-MIP to increase the genetic gains from selection among the extra-early maturing maize in SSA [29,30].

The range of grain yield values, from $1389 \mathrm{~kg} \mathrm{ha}^{-1}$ for period 1 hybrids to $1659 \mathrm{~kg} \mathrm{ha}^{-1}$ for period 3 hybrids provided confirmation of the genetic advances made in the most recent breeding period. The relative genetic gain of $4.1 \%$ per year obtained for the period 3 hybrids under drought conditions in the present study which is considerably larger compared to the $0.41 \%$ per year obtained when late maturing maize varieties developed from 1970 to 1999 were evaluated under drought conditions in West Africa [28]. The per cent gain per year obtained under drought environments in the current study is also greater than the 1.93\% per year documented by Badu-Apraku et al. [23] as well as Oyekunle et al. [26] (2019) when 24 open-pollinated extra-early maize varieties were assessed under drought environments at Kadawa and Zaria in the 2015/2016 and 2016/2017 dry seasons in Nigeria. Furthermore, the relative genetic gain of $2.97 \%$ per year observed under rainfed management conditions is markedly larger than the $1.93 \%$ per year reported by Oyekunle et al. [26] for early maturing hybrids under similar research conditions in Nigeria. Additionally, the $2.97 \%$ annual genetic gain obtained under rainfed conditions in this study significantly surpassed the 1.7\% annual gain in GY obtained by Tollenaar [48] when commercial maize hybrids were evaluated for about three decades (from the late 1950s to 1980) in Central Ontario in Canada under favorable environmental conditions.

The significant and positive correlation found between GY and plant and ear heights measured for the hybrids across varying soil moisture regimes and different periods suggested that taller and vigorous hybrids might have produced and translocated a large amount of assimilates for grain filling which might have contributed to high GY. Similarly, the significant and positive relationship observed between GY and EPP generally implied that the production of more than one well-filled ear per plant and that prolificacy was a 
major factor contributing to the increased grain yield of the hybrids [49]. Contrarily, days to silking, and ASI recorded significant and negative correlations with grain yield. This finding indicated that genetic gain in GY of the hybrids was associated with early anthesis and silking $[50,51]$ across the three different periods. The significant and negative correlations detected between the STGR and plant and ear heights under drought conditions also suggested that leaf senescence was delayed among the tall and robust hybrids, an indication of the good grain-filling ability which is an important physiological process beneficial to drought-tolerant maize genotypes [52-54]. The stay-green characteristic was identified as a direct factor that contributed to high GY under moisture-limiting conditions at flowering and during the commencement of grain filling [55,56]. However, STGR had a significant and positive correlation with PASP, stalk and root lodging, husk cover, and ear rot under drought conditions. It could therefore be deduced that genotypes that experienced delayed senescence also had significantly reduced root and stalk lodging with very tight husk cover to reduce the rate of disease and pest incidence on the ears. It was thus not surprising to find such genotypes from period 3 producing well-filled ears with no or very limited number of ears showing ear rot.

A relatively greater proportion of the variation $(64 \%)$ among the top-performing hybrids of periods 1, 2, and 3 was explained by the principal components 1 and 2 of the GGE biplot analysis. This suggested that the GGE biplot was efficient in decomposing the overall variation among the hybrids to identify superior candidates across drought and rainfed conditions (14 research environments). In the biplot display in Figure 3B, the double arrowed line separated the hybrids that yielded below the average yield from those that yielded above the average yield. Thus, the farther the hybrid to the left side of the double arrowed line, the lower the yield while the farther the hybrid was to the right side of the double arrowed line, the higher was the yield. In terms of stability, the longer the projection of a hybrid onto the single-arrowed line, the lower was the stability of the hybrid while the shorter the projections, the greater was the stability [57]. Based on this interpretation, TZdEEI $64 \times$ TZEEI 54, and (TZEEI $29 \times$ TZEEI 13) $\times$ TZdEEI 64, hybrids developed in period 3, and TZEEI $112 \times$ TZEEI 29 and (TZEEI $29 \times$ TZEEI 14) $\times$ TZdEEI 10 developed in period 2 were the highest yielding across the nine research locations among which TZEEI $112 \times$ TZEEI 29 was the most stable hybrid. (TZEEI $95 \times$ TZEEI 58) $\times($ TZEEI $82 \times$ TZEEI 79) from Period 1 , (TZdEEI $12 \times$ TZEEI 58) and (TZdEEI $11 \times$ TZdEEI 79) from period 2 were the worst-performing hybrids. The high-yielding and stable hybrids are recommended for further testing on-farm for consistent performance and commercialized in SSA. The performance of the hybrids developed in period 3 therefore reflected the greater genetic gains achieved in period 3.

In the which-won where polygon view, the axes projecting from the origin separated the biplot into sectors or environments, with the hybrids at the vertices of each sector representing the best performing hybrid(s) within the respective sectors. This accelerated the process of identifying the superior hybrids for specific environments [57,58]. From the polygon view, (TZEEI $29 \times$ TZEEI 14) $\times$ TZEEI 10 was the most outstanding hybrid under rainfed conditions at Zaria (2017), Ikenne (2017), and Bagauda (2017), and under drought conditions at Ikenne (2016, 2018, and 2019). Hybrid TZEEI $100 \times$ TZEEI 63 was more adapted to rainfed conditions at Kadawa and Zaria in 2016 while 2009 TZEE-OR1 STR $\times$ TZdEEI 7 was better adapted to rainfed conditions at Ikenne (2016).

In conclusion, the study has revealed considerably high genetic gains $(4.1 \%)$ per year for GY of the extra-early hybrids evaluated under drought conditions in Nigeria. Six out of the top ten hybrids evaluated under managed drought were from period 3 compared to the two hybrids each from periods 2 and 1, respectively. This indicated that high genetic gains from selection for improved GY under moisture stress had been made in period 3. Hybrid TZEEI $112 \times$ TZEEI 29 came out as the highest yielding with very high stability under all the test environments while (TZEEI $29 \times$ TZEEI 14$) \times$ TZEEI 10 had broad adaptation with moderate (just above average) GY. It is therefore necessary to widely test these two hybrids 
for consistent performance especially, under drought conditions for commercialization in SSA.

Author Contributions: Conceptualization, B.B.-A.; formal analysis, O.O., A.A., E.O.-B.; genetic resources, B.B.-A., data curation, O.O., A.A.; writing-review \& editing, B.B.-A., O.O., E.O.-B.; funding acquisition, B.B.-A. All authors have read and agreed to the published version of the manuscript.

Funding: This research was funded by the Bill and Melinda Gates Foundation (Grant/ Award Number: OPP1134248) under the Stress Tolerant Maize for Africa (STMA) Project of IITA.

Institutional Review Board Statement: Not applicable.

Informed Consent Statement: Not applicable.

Data Availability Statement: The datasets used in the present study are available at the IITA CKAN repository.

Conflicts of Interest: The authors declare no conflict of interest.

\section{References}

1. FAOSTAT. 2018. Food and Agriculture Organisation Data Base on Imputation Methodology. Available online: http://www.fao. org/faostat/en/\#data/QC (accessed on 2 January 2021).

2. Shiferaw, B.; Prasanna, B.M.; Hellin, J.; Banziger, M. Crops that feed the world. 6. Past successes and future challenges to the role played by maize in global food security. Food Secur. 2011, 3, 307-327. [CrossRef]

3. Badu-Apraku, B.; Fakorede, M.A.B. Advances in Genetic Enhancement of Early and Extra-Early Maize for Sub-Saharan Africa; Springer International Publishing: Cham, Switzerland, 2017. [CrossRef]

4. Akaogu, I.C.; Badu-Apraku, B.; Adetimirin, V.O. Combining ability and performance of extra-early maturing yellow maize inbreds in hybrid combinations under drought and rain-fed conditions. J. Agric. Sci. 2017, 155, 1520-1540. [CrossRef]

5. Kamara, A.Y.; Menkir, A.; Omogui, L.O.; Kureh, I. Potential of drought tolerant maize varieties in nitrogen deficient soils of the Guinea Savanna. In Demand-Driven Technologies for Sustainable Maize Production in West and Central Africa; Scientific Papers Presented at the Regional Workshop of the West and Central Africa Collaborative Maize Research Network (WECAMAN) Held at, IITA-Ibadan; Badu Apraku, B., Fakorede, M.A.B., Lum, A.F., Menkir, A., Ouedraogo, M., Eds.; International Institute of Tropical Agriculture: Ibadan, Nigeria, 2005; pp. 180-193.

6. Lobulu, J.; Shimelis, H.; Laing, M.; Mushongi, A.A. Maize production constraints, traits preference and current Striga control options in western Tanzania: Farmers' consultation and implications for breeding. Acta Agriculturae Scandinavica, Section B. J. Plant Nutr. Soil Sci. 2019, 69, 734-746.

7. Fakorede, M.A.B.; Akinyemiju, O.A. Climatic change: Effects on maize production in a tropical rainforest location. In Maize Revolution in West and Central Africa, Proceedings of the Regional Maize Workshop, IITA-Cotonou, Benin Republic, 14-18 May 2001; Badu-Apraku, B., Ed.; WECAMAN/IITA: Ibadan, Nigeria, 2003; pp. 272-282.

8. Campos, H.; Cooper, M.; Edmeades, G.O.; Löffler, C.; Schussler, J.R.; Ibañez, M. Changes in drought tolerance in maize associated with fifty years of breeding for yield in the U.S. corn belt. Maydica 2006, 51, 369-381.

9. Badu-Apraku, B.; Fakorede, M.A.B.; Oyekunle, M.; Akinwale, R.O. Selection of extra-early maize inbreds under low N and drought at flowering and grain-filling for hybrid production. Maydica 2011, 56, 1721-1735.

10. Badu-Apraku, B.; Oyekunle, M. Genetic analysis of grain yield and other traits of extra-early yellow maize inbreds and hybrid performance under contrasting environments. Field Crops Res. 2012, 129, 99-110. [CrossRef]

11. Badu-Apraku, B.; Fakorede, M.A.B.; Menkir, A.; Kamara, A.Y.; Akanvou, L.; Chabi, Y. Response of early maturing maize to multiple stresses in the Guinea savanna of West and Central Africa. Int. J. Plant Breed. Genet. 2004, 58, 119-130.

12. Bänziger, M.; Edmeades, G.O.; Beck, D.; Bellon, M. Breeding for Drought and Nitrogen Stress Tolerance in Maize: From Theory to Practice; CIMMYT: Mexico City, Mexico, 2000.

13. Badu-Apraku, B.; Yallou, C.G.; Haruna, A.; Talabi, A.O.; Akaogu, I.C.; Annor, B.; Adeoti, A. Genetic improvement of extra-early maize cultivars for grain yield and Striga resistance during three breeding eras. Crop Sci. 2016, 56, 2564-2578. [CrossRef]

14. Badu-Apraku, B.; Ewool, M.; Yallou, C.G. Registration of Striga -resistant tropical extra-early maize population. J. Plant Regist. 2010, 4, 60-66. [CrossRef]

15. Cairns, J.E.; Hellin, J.; Sonder, K.; Araus, J.L.; MacRobert, J.F.; Thierfelder, C.; Prasanna, B.M. Adapting maize production to climate change in sub-Saharan Africa. Food Secur. 2013, 5, 345-360. [CrossRef]

16. Ndwiga, J.; Pittchar, J.; Musyoka, P.; Nyagol, D.; Marechera, G.; Omanya, G.; Oluoch, M. Integrated Striga Management in Africa Project; Constraints and Opportunities of Maize Production in Western Kenya: A Baseline Assessment of Striga Extent, Severity, and Control Technologies; Integrated Striga Management in Africa (ISMA); International Institute of Tropical Agriculture: Ibadan, Nigeria, 2013.

17. Talabi, A.O.; Badu-Apraku, B.; Fakorede, M.A.B. Genetic Variances and Relationship among Traits of an Early-maturing Maize Population under Drought-stress and Low N Environments. Crop Sci. 2017, 57, 1-12. [CrossRef] 
18. NeSmith, D.S.; Ritchie, J.T. Effects of soil water deficit during tessel emergence on development and yield component of maize (Zea mays L.). Field Crops Res. 1992, 28, 251-256. [CrossRef]

19. Moss, G.I.; Downey, L.A. Influence of drought stress on female gametophyte development in corn (Zea mays L.) and subsequent grain yield. Crop Sci. 1971, 11, 368-372. [CrossRef]

20. Hall, A.J.; Vilella, F.; Trapani, N.; Chimenti, C. The effects of water stress and genotype on the dynamics of pollen-shedding and silking in maize. Field Crops Res. 1982, 5, 349-363. [CrossRef]

21. Edmeades, G.O.; Bolanos, J.; Lafitte, H.R. Progress in breeding for drought tolerance in maize. In Proceedings of the 47th Ann. Corn and Sorghum Industry Research Conference., Chicago, IL, USA, 8-10 December 1992; Wilkinson, D., Ed.; ASTA: Washington, DC, USA, 1992; pp. 93-111.

22. Badu-Apraku, B.; Yallou, C.G.; Oyekunle, M. Genetic gains from selection for high grain yield and Striga resistance in early maturing maize cultivars of three breeding periods under Striga-infested and Striga-free environments. Field Crops Res. 2013, 147, 54-67. [CrossRef]

23. Badu-Apraku, B.; Talabi, A.O.; Ifie, B.E.; Chabi, Y.C.; Obeng-Antwi, K.; Haruna, A.; Asiedu, R. Gains in grain yield of extra-early maize during three breeding periods under drought and rainfed conditions. Crop Sci. 2018, 58, 2399-2412. [CrossRef]

24. Annor, B.; Badu-Apraku, B. Gene action controlling grain yield and other agronomic traits of extra-early quality protein maize under stress and non-stress conditions. Euphytica 2016, 212, 213-228. [CrossRef]

25. Oyekunle, M.; Ado, S.G.; Usman, I.S.; Abdulmalik, R.O.; Ahmed, H.O.; Hassan, L.B.; Yahaya, M.A. Gains in grain yield of released maize (Zea mays L.) cultivars under drought and well-watered conditions. Exp. Agric. 2019, 55, 934-944. [CrossRef]

26. O'Neill, P.M.; Shanahan, J.F.; Schepers, J.S.; Caldwell, B. Agronomic responses of corn hybrids from different eras to deficit and adequate levels of water and nitrogen. Agron. J. 2004, 96, 1660-1667. [CrossRef]

27. Kamara, A.Y.; Menkir, A.; Fakorede, M.A.B.; Ajala, S.O.; Badu-Apraku, B.; Kureh, I. Agronomic performance of maize cultivars representing three decades of breeding in the Guinea savannas of West and Central Africa. J. Agric. Sci. 2004, 142, 567-575. [CrossRef]

28. Badu-Apraku, B.; Fakorede, M.A.B.; Oyekunle, M.; Akinwale, R.O. Genetic gains in grain yield under nitrogen stress following three decades of breeding for drought tolerance and Striga resistance in early maturing maize. J. Agric. Sci. 2015, 154, 647-661. [CrossRef]

29. Badu-Apraku, B.; Yallou, C.G.; Obeng-Antwi, K.; Alidu, H.; Talabi, A.O.; Annor, B.; Oyekunle, M.; Akaogu, I.C.; Aderounmu, M. Yield gains in extra-early maize cultivars of three breeding eras under multiple environments. Agron. J. 2017, 109, 1-14. [CrossRef]

30. Badu-Apraku, B.; Fakorede, M.A.B. Breeding early and extra-early maize for resistance to biotic and abiotic stresses in sub-Saharan Africa. Plant Breed. Rev. 2013, 37, 123-205.

31. Badu-Apraku, B.; Yallou, C.G. Registration of Striga-resistant and drought-tolerant tropical early maize populations TZE-W Pop DT STR C 4 and TZE-Y Pop DT STR C 4. J. Plant Regist. 2009, 3, 86-90. [CrossRef]

32. Badu-Apraku, B.; Fakorede, M.A.B. Progress in breeding for Striga hermonthica resistant early and extra-early maize varieties. In Impact, Challenges and Prospects of Maize Research and Development in West and Central Africa, Proceedings of the Regional Maize Workshop, 4-7 May 1999; Badu-Apraku, B., Fakorede, M.A.B., Ouedraogo, M., Quin, M., Eds.; WECAMAN/IITA-Cotonou: Cotonou, Benin, 2001; pp. 147-162.

33. Badu-Apraku, B.; Fakorede, M.A.B.; Lum, A.F. Evaluation of experimental varieties from recurrent selection for Striga resistance in two extra-early maize populations in the savannas of West and Central Africa. Exp. Agric. 2007, 43, 183-200. [CrossRef]

34. Badu-Apraku, B.; Fakorede, M.A.B.; Lum, A.F. $\mathrm{S}_{1}$ family selection in early maturing maize population in Striga-infested and Striga-free environments. Crop Sci. 2008, 48, 1984-1994. [CrossRef]

35. Badu-Apraku, B.; Fakorede, M.A.B.; Lum, A.F.; Akinwale, R.O. Improvement of yield and other traits of extra-early maize under stress and nonstress environments. J. Agron. 2009, 101, 381-389. [CrossRef]

36. SAS Institute. SAS System for Windows; Release 9.4.; SAS Institute Inc.: Cary, NC, USA, 2012.

37. Fehr, W.R. Principles of Cultivar Development: Theory and Technique; Iowa State University: Ames, IA, USA, 1991 ; Volume 1.

38. Yan, W. GGE biplot: A windows application for graphical analysis of multi-environment trial data and other types of two-way data. Agron J. 2001, 93, 1111-1118. [CrossRef]

39. Obeng-Bio, E.; Badu-Apraku, B.; Ifie, B.E.; Danquah, A.; Blay, E.T.; Annor, B. Genetic analysis of grain yield and agronomic traits of early provitamin A quality protein maize inbred lines in contrasting environments. J. Agric. Sci. 2019, 157, 413-433. [CrossRef]

40. Eitzinger, J.; Trnka, M.; Hösch, J.; Žalud, Z.; Dubrovský, M. Comparison of CERES, WOFOST and SWAP models in simulating soil water content during growing season under different soil conditions. Ecol. Model. 2004, 171, 223-246. [CrossRef]

41. Zali, H.; Farshadfar, E.; Sabaghpour, S.H. Non-parametric analysis of phenotypic Stability in chickpea (Cicer arietinum L.) genotypes in Iran. CBJ 2011, 1, 89-100.

42. Sabaghnia, N.; Sabaghpour, S.H.; Dehghani, H. The use of an AMMI model and its parameters to analyse yield stability in multi-environment trials. J. Agric. Sci. 2008, 146, 571-581. [CrossRef]

43. Moghaddam, M.J.; Pourdad, S.S. Comparison of parametric and non-parametric methods for analyzing genotype $\times$ environment interactions in safflower (Carthamus tinctorius L.). J. Agric. Sci. 2009, 147, 601-612. [CrossRef]

44. Edmeades, G.O.; Bolaños, J.; Chapman, S.C.; Lafitte, H.R.; Bänziger, M. Selection improves drought tolerance in tropical maize populations: I. Gains in biomass, grain yield, and harvest index. Crop Sci. 1999, 39, 1306-1315. [CrossRef] 
45. Badu-Apraku, B.; Oyekunle, M.; Menkir, A.; Obeng-Antwi, K.; Yallou, C.G.; Usman, I.S.; Alidu, H. Comparative performance of early maturing maize cultivars developed in three eras under drought stress and well-watered environments in West Africa. Crop Sci. 2013, 53, 1298-1311. [CrossRef]

46. Bänziger, M.; Edmeades, G.O.; Lafitte, H.R. Selection for drought tolerance increases maize yields over a range of N levels. Crop Sci. 1999, 39, 1035-1040. [CrossRef]

47. Berner, D.K.; Alabi, M.O.; Di-Umba, U.; Ikie, F.O. Proposed integrated control program for Striga hermonthica in Africa. In Proceedings of the 6th Parasitic Weeds Symposium, Cordoba, Spain, 16-18 April 1996; pp. 817-825.

48. Tollenaar, M. Response of dry matter accumulation in maize to temperature. II Leaf photosynthesis. Crop Sci. 1989, 29, 1275-1279. [CrossRef]

49. Sadras, V.O.; Lawson, C. Genetic gain in yield and associated changes in phenotype, trait plasticity and competitive ability of South Australian wheat varieties released between 1958 and 2007. Crop. Pasture Sci. 2011, 62, 533-539. [CrossRef]

50. Siddique, K.H.M.; Kirby, E.J.M.; Perry, M.W. Ear: Stem ratio in old and modern wheat varieties; relationship with improvement in number of grains per ear and yield. Field Crops Res. 1989, 21, 59-78. [CrossRef]

51. Giunta, F.; Motzo, R.; Pruneddu, G. Trends since 1900inthe yield potential of Italian-bred durum wheat cultivars. Eur. J. Agron. 2007, 27, 12-24. [CrossRef]

52. Ma, M.L.; Dwyer, M.L. Nitrogen uptake and use in two contrasting maize hybrids differing in leaf senescence. J. Plant Nutr. Soil Sci. 1998, 199, 283-291.

53. Blum, A. Drought resistance, water-use efficiency, and yield potential: Are they compatible, dissonant, or mutually exclusive? Aust. J. Agric. Res. 2005, 56, 1159-1168. [CrossRef]

54. Blum, A. Drought adaptation in cereal crops: A prologue. In Drought Adaptation in Cereals; Ribaut, J.-M., Ed.; The Haworth Press Inc.: Binghamton, NY, USA, 2006; pp. 3-15.

55. Ribaut, J.M.; Bänziger, M.; Setter, T.; Edmeades, G.; Hoisington, D. Genetic dissection of drought tolerance in maize: A case study. In Physiology and Biotechnology Integration for Plant Breeding; Nguyen, H., Blum, A., Eds.; Marcel Dekker Inc.: New York, NY, USA, 2004; pp. 571-611.

56. Duvick, D.N. The contribution of breeding to yield advances in maize (Zea mays L). Adv. Agron. 2005, 86, 83-145.

57. Yan, W.; Kang, M.S.; Ma, S.; Woods, S.; Cornelius, P.L. GGE biplot vs. AMMI analysis of genotype-by-environment data. Crop Sci. 2007, 47, 596-605. [CrossRef]

58. Yan, W.; Fregeau-Reid, J.; Pageau, D.; Martin, R.; Mitchell-Fetch, J.; Etienne, M.; Rowsell, J.; Scott, P.; Price, M.; de Haan, B.; et al. Identifying essential test locations for oat breeding in Eastern Canada. Crop Sci. 2010, 50, 505-515. [CrossRef] 